ФОРМУВАННЯ ОСНОВ ВЕБ-ОРІЕНТОВАНИХ ТЕХНОЛОГІЙ НА УРОКАХ ІНФОРМАТИКИ В УЧНІВ СТАРШИХ КЛАСІВ ЗАКЛАДІВ ЗАГАЛЬНОї СЕРЕДНЬОÏ ОСВІТИ

\title{
FORMATION OF FUNDAMENTALS OF VEBORIENT-FRIENDLY TECHNOLOGIES IN INFORMATICS LESSONS IN SENIOR STUDENTS OF GENERAL SECONDARY EDUCATION INSTITUTIONS
}

Розглянуто теоретичні основи інформатизації освіти та стратегічні напрями державної політики у сорері закладів загальної середньої освіти з урахуванням реформування системи освіти, в основу якої покладатиметься принцип пріоритетності людини; оновлення згідно з вимогами часу нормативної бази, модернізації структури, змісту й організації освіти на засадах компетентнісного підходу, забезпечення доступності та безперервності освіти протягом усього життя, розвитку наукової та інноваційної діяльності в освіті, підвищення якості освіти на інноваційній основі, інформатизації освіти, вдосконалення бібліотечного mа інорормаційно-ресурсного забезпечення освіти та науки; створення сучасної матеріально-технічної бази. Виокремлено основні шляхи формування циорової компетентності та їі концептуальні моделі, охарактеризовано ключові складники цисрової компетентності учнів старших класів закладів загальної середньої освіти. Розглянуто теоретичні та методичні аспекти формування основ веб-орієнтованих технологій на уроках інсрорматики в учнів старших класів закладів загальної середньої освіти в рамках формування основ веб-орієнтованих технологій, використання веб-програмування у навчанні інорорматики та їі впровадження із зазначеними суперечностями між зростаючим рівнем інформатизації суспільства і недостатньо ефективним використанням цифрових технологій у закладах загальноі середньої освіти та можливостями використання веб-орієнтованих технологій у процесі навчання інформатики відповідно до методичних систем навчання. Запропоновано впровадження та використання веб-орієнтованих технологій для навчання інформатики у закладах загальної середньої освіти з веб-орієнтованою методичною системою навчання інформатики, котра $\epsilon$ сукупністю взаємопов'язаних компонентів: цілей, змісту, методів, засобів та організаційних форм навчання інформатики, що утворюють єдину цілісну ффункціональну структуру, орієнтовану на педагогічно виважене використання веб-технологій для досягнення освітніх цілей. Розглянуто недоречності у формуванні цифррової освіти в Україні, а саме недостатню мотивацію учасників освітнього процесу до використання цисррових технологій в освітньому прочесі, недосконалість нормативно-правової бази.

Ключові слова: інформатизація освіти освітній процес, освітнє середовище, здо- бувачі освіти, методична система навчання, цифрові технології.

The theoretical bases of informatization of education and strategic directions of the state policy in the field of education of general secondary education institutions are considered, taking into account the reform of the education system, which will be based on the principle of human priority; updating the regulatory framework of the education system in accordance with the requirements of the time; modernization of the structure, content and organization of education on the basis of the competence approach ensuring the availability and continuity of lifelong learning; development of scientific and innovative activities in education, improving the quality of education on an innovative basis; informatization of education, improvement of library and information-resource provision of education and science; creation of a modern material and technical base of the education system. The main ways of formation of digital competence and its conceptual models are singled out, the key components of digital competence of senior pupils of general secondary education institutions are characterized. Theoretical and methodological aspects of forming the basics of web-oriented technologies in computer science lessons for high school students in general secondary education in the formation of the basics of web-oriented technologies, the use of web programming in computer science and its implementation with these contradictions between the growing level of informatization of society and inefficient use of digital general secondary education institutions and the possibilities of using web-oriented technologies in the process of teaching computer science and in accordance with methodological systems of education. The introduction and use of web-oriented technologies for teaching computer science in general secondary education institutions with a web-oriented methodological system of computer science teaching is a set of interconnected components: goals, content, methods, tools and organizational forms of computer science teaching. on expedient and pedagogically balanced use of web technologies to achieve educational goals. Inadequacies in the formation of digital education in Ukraine are considered, namely the lack of motivation of participants in the educational process to use digital technologies in the educational process, the imperfection of the regulatory framework.

Key words: informatization of education, educational process, educational environment, students, methodical system of education, digital technologies.
Постановка проблеми в загальному вигляді. Модернізація і розвиток освіти повинні набути випереджального безперервного характеру, гнучко реагувати на всі процеси, що відбуваються в Укра- їні та світі. Підвищення якісного рівня освіти має бути спрямоване на забезпечення економічного зростання держави та розв'язання соціальних проблем суспільства, подальше навчання і розви- 
ток особистості. Якісна освіта $€$ необхідною умовою забезпечення сталого демократичного розвитку суспільства [6]. Важливим фрактором сучасної шкільної освіти $€$ рівень готовності школярів до сучасних методик опрацювання інорормації. Способи передачі інформації дедалі більше набувають цифрового формату, а уміння знаходити, аналізувати та представляти інформацію впливає на вивчення всього комплексу шкільних дисциплін, адже освіта має працювати на випередження, відповідати тенденціям розвитку суспільства в майбутньому та забезпечувати реалізацію ідей сталого розвитку.

«Національна стратегія розвитку освіти в Україні на період до 2021 року» [6] зазначає, що «розбудова національної системи освіти за сучасних умов з урахуванням кардинальних змін у всіх сореpax суспільного життя, історичних викликів XXI ст. вимагає критичного осмислення досягнутого та зосередження зусиль і ресурсів на розв'язанні найбільш гострих проблем, які стримують розвиток, не дають можливості забезпечити нову якість освіти, адекватну нинішній історичній епосі».

Стратегічними напрямами державної політики у сорері освіти повинні стати: реорормування системи освіти, в основу якої покладатиметься принцип пріоритетності людини; оновлення згідно 3 вимогами часу нормативної бази системи освіти; модернізація структури, змісту й організації освіти на засадах компетентнісного підходу; забезпечення доступності та безперервності освіти протягом усього життя; розвиток наукової та інноваційної діяльності в освіті, підвищення якості освіти на інноваційній основі; інформатизація освіти, вдосконалення бібліотечного та інформаційноресурсного забезпечення освіти та науки; створення сучасної матеріально-технічної бази системи освіти [6].

Серед зазначених проблем актуальними $€$, зокрема, повільне здійснення інформатизації системи освіти, впровадження в освітній процес інноваційних та інфрормаційно-комунікаційних технологій. У зв'язку з цим постала проблема орормування у майбутніх фахівців цифрових компетентностей.

Цифрова компетентність є однією 3 найбільш важливих для сучасної людини та дозволить реалізуватися в сучасному суспільстві професійно та соціально. Цифрові компетентності передбачають впевнене і водночас критичне застосування новітніх технологій для створення, пошуку, обробки, обміну інорормацією на роботі, в публічному просторі та приватному спілкуванні. Цифрова та медіаграмотність, основи програмування, алгоритмічне мислення, робота з базами даних, навички безпеки в інтернеті, кібербезпека, розуміння етики роботи 3 інформацією (авторського права, інтелектуальної власності тощо) (Концепція нової української школи, 2018) - цьому сприяє вивчення предмету «Інформатика» в закладах загальної середньої освіти. Суттєвий внесок у формування цифрових компетентностей робить вивчення веборієнтованих технологій і веб-програмування.

Аналіз останніх досліджень і публікацій. Теоретичні засади інформатизації освіти, використання цифрових технологій розкриваються у психолого-педагогічних працях Н. Балик, Ю. Батури, Н. Гончарової, О. Грибюк, О. Патрикеєвої, О. Стрижак, О. Співаковського, О. Шевчук та ін.; концептуальні основи фрормування цифрових компетентностей здобувачів освіти - у роботах В. Бикова, Р. Гуревича, Ю. Дорошенка, М. Жалдака, О. Карабін, Ю. Рамського, О. Спіріна, С. Семерікова, О. Співаковського, Н. Морзе, О. Мороза, М. Шкіля та ін.

Виділення не вирішених раніше частин загальної проблеми. Головною метою інфрорматизації освітнього процесу закладів загальної середньої освіти є підготовка здобувачів освіти до життєдіяльності у діджиталізованому суспільстві: формування цифрової культури здобувачів освіти, розвиток їхніх здібностей, розкриття творчого потенціалу. В. Биков називає інформатизацію освіти справжньою революцією в освіті, в якій, спираючись на здобутки класичної психолого-педагогічної науки, розробляються специорічні завдання створення й ефективного впровадження цифрових технологій в освітню практику [2].

Розвиток цифрових технологій призвів до змін і в освіті. Питаннями розробки та впровадження методичних систем навчання інформатики у 10-11 класах закладів загальної середньої освіти як предмета займалися багато українських учених, зокрема М. Жалдак, Н. Морзе, Ю. Рамський та ін. Науковці зауважують, що за умов широкого використання засобів цифррових технологій в освітньому процесі «значно зростають вимоги до профресійної підготовки вчителя, до обсягу його знань, культури мови, спілкування, поведінки» [7].

Основні шляхи фрормування цифрової компетентності та її концептуальні моделі окреслено у науковому проекті DigComp (The European Digital Competence Framework for Citizens). До ключових складників цифрової компетентності доцільно віднести: технологічну складову частину, яка полягає в навичках володіння циоровими технологіями для виконання необхідних в інформаційному суспільстві завдань; алгоритмічну, що передбачає уміння конструювання та використання алгоритмів, розуміння ролі комп'ютера в конструюванні та виконанні алгоритмів, опанування сучасних систем розробки програмного забезпечення; модельну, яка полягає у володінні базовими поняттями теорії моделей, усвідомленні понять комп'ютерного моделювання, умінні використовувати різноманітні профресійні пакети комп'ютерного моделювання в освітній галузі; дослідницьку, що вимагає усвідом- 
лення комп'ютера як універсального технічного засобу для автоматизації освітніх досліджень, навичок володіння цифровими технологіями та їх застосування у професійній діяльності; методологічну, яка допомагає опанувати розуміння можливостей і доцільності використання цифрових технологій для розв'язання соціальних та індивідуальних завдань сьогодення та майбутнього.

Важливо зазначити, що використання цисррових технологій в освітньому процесі не полегшує роботи вчителя. Насамперед кожному вчителю необхідно чітко усвідомити, як саме раціонально, алгоритмічно вибудувати ті чи інші цифрові засоби, вивчаючи конкретну тему, щоб ефективно навчати учнів та отримати належний результат. На сучасному етапі розвитку освіти цифрові технології незамінні для організації спільної діяльності вчителів та учнів, оскільки їх використання сприяє розв'язанню багатьох дидактичних завдань. Тож цифрові технології $\epsilon$ інструментом розвитку інтелектуальних здібностей, фрормування цифрової грамотності, потенціалу та готовності старшокласників до розв'язання на творчій основі комунікативних і комунікаційних завдань і проблем, які чекають на них у майбутній професійній діяльності. Цифрова компетентність учителя «повинна фрормуватися одночасно у двох напрямах: 3 одного боку, це фрормування користувацьких умінь у сорері цифрових технологій, $з$ іншого - фрормування умінь використання цифрових технологій як ефективного засобу для підвищення якості освіти» [4].

Нині триває процес розроблення освітніх стандартів стосовно навчання природничо-математичних дисциплін, у т. ч. інформатики, у закладах загальної середньої освіти. У зв'язку з цим проблема фрормування основ веб-орієнтованих технологій, використання веб-програмування у навчанні інорорматики потребує ґрунтовного дослідження, а їі вивчення пов'язане із суперечностями: між зростаючим рівнем інформатизації суспільства і недостатньо ефективним використанням цифрових технологій у закладах загальної середньої освіти та можливостями використання веб-орієнтованих технологій у процесі навчання інорорматики та інших предметів, відсутністю відповідних методичних систем навчання.

Мета статті полягає у розгляді теоретичних і методичних аспектів формування основ веборієнтованих технологій на уроках інформатики в учнів старших класів закладів загальної середньої освіти.

Виклад основного матеріалу. Значну роль у формуванні цифрових компетентностей здобувачів освіти основної школи відіграє вивчення принципів роботи створення веб-сайтів із використання мови HTM, CSS, PHP, Java Script, Pyton. Метою вивчення веб-програмування $€$ формування в учнів циоррових компетентностей, впровадження основ веб-орієнтованих технологій в освітній процес, позакласну роботу для здобуття знань, вмінь і навичок у подальшій діяльності.

Сьогодні існує небагато програм для вивчення веб-орієнтованих технологій у старшій школі закладів загальної середньої освіти. Вважаємо, що учні, які навчаються за новою програмою, та школярі, котрі вивчатимуть шкільні дисципліни за програмою Нової української школи, вже більш обізнані у галузі цифрових технологій, тож використання веб-орієнтованих технологій для навчання інформатики у закладах загальної середньої освіти є підґрунтям подальшого розвитку комп'ютерно-орієнтованих систем. Веб-орієнтована методична система навчання інорорматики є сукупністю взаємопов'язаних компонентів: цілей, змісту, методів, засобів і організаційних фрорм навчання інформатики, що утворюють єдину цілісну фрункціональну структуру, орієнтовану на доцільне та педагогічне виважене використання веб-технологій для досягнення цілей навчання. Складовою частиною веб-орієнтованої методичної системи навчання інорорматики учнів старших класів $€$ веб-орієнтована методична система навчання комп'ютерної верстки та вебпрограмування, важливими компонентами яких $€$ зміст (програма курсу за вибором «Основи верстки та веб-програмування») та засоби навчання (веборієнтовані технології). Основні компоненти цієї системи реалізовано в курсі за вибором «Основи верстки та веб-програмування».

Програма курсу за вибором, чинна сьогодні, складається із двох змістових ліній:

- основи комп'ютерної верстки та дизайну поліграфрічної продукції;

- основ комп'ютерної верстки та дизайну сайтів із вивченням основ веб-програмування.

Основою курсу за вибором «Основи верстки та веб-програмування» [5] (лист Інституту модернізації змісту освіти від 28 липня 2017 р. № 211/12Р-465) у закладах загальної середньої освіти став посібник «Вивчення веб-програмування в школі» [7]. Також слід згадати програми курсів за вибором «Основи інтернет» [4], «Основи веб-дизайну» [3], оволодіння якими сприяє фрормуванню у здобувачів освіти розуміння принципів організації веб-ресурсів, розвитку навичок роботи з програмними засобами розробки веб-сторінок, а також вихованню культури оформлення сайтів та умінь структурування даних тощо. Проте у цих курсах за вибором не розкрито питання застосування таблиць каскадних стилів і технології створення динамічних веб-сторінок.

Це питання подано у програмі «Основи верстки та веб-програмування» (автори А. Кузьменко, О. Рибак). Програма розрахована на учнів старших класів закладів загальної середньої освіти. Вона 
$€$ логічним продовженням вивчення інфрорматики базової школи й орієнтована на класи, що працюють за освітніми планами з академічним рівнем навчання інорорматики, а також може використовуватися для вивчення предмету «Технології». Проте, враховуючи різнорівневе вивчення інфрорматики у старших класах, кожен розділ програми можна використовувати окремо або обрати кілька розділів, наприклад, HTML, CSS i Java Script.

Основою навчання інфрорматики у 10-11 класах нині є базовий модуль, зміст якого може бути розширений за рахунок вибіркових. Базовий модуль, на вивчення якого відводиться 35 годин, завершує фрормування в учнів предметних і ключових компетентностей щодо використання цифрових технологій на рівні, визначеному чинним державним стандартом базової та повної загальної середньої освіти. Цей модуль є мінімально допустимою нерозривною структурною одиницею програми. Вибіркові модулі для розширення курсу вчитель добирає відповідно до профрілю навчання у закладі освіти, запитів, індивідуальних інтересів і здібностей здобувачів освіти, регіональних особливостей, матеріально-технічної бази й наявного програмного забезпечення. Майже всі розділи програми за змістом і вимогами до освітніх досягнень збігаються із відповідними курсами за вибором $з$ інформатики, можливо, в дещо ущільненому варіанті. Тому для навчання цих розділів рекомендовано використовувати навчально-методичне забезпечення для курсів за вибором.

В основу курсу інорорматики сучасної школи покладений розвивально-компетентнісний підхід, що передбачає орормування предметних знань, а також розвиток мислення, насамперед алгоритмічного. Ознайомившись із переліченими програмами та курсами, відзначимо, що сьогодні існують й інші технології створення веб-сайтів. Учні, які працюватимуть із цією програмою та в майбутньому продовжать навчання в напрямі веб-програмування, не зможуть використати свої знання на практиці, оскільки з'являються нові технології. Вважаємо, що доцільно під час розробки модулів і курсів за вибором для учнів 10-11 класів подавати теми щодо розробки сайтів із використанням не тільки інтерпретованих мов РНР i Java, але й мови програмування Python і вебфрреймворку Django. Django - це високоякісний веб-фреймворк Python, який дозволяє швидко розвивати безпечні та ремонтопридатні вебсайти, а також підходить для створення майже будь-якого типу веб-сайтів - від систем управління вмістом і вікі до соціальних мереж, сайтів новин. Django може працювати з будь-якою клієнтською структурою та представляти вміст у будь-якому фрорматі (включаючи HTML, RSSканали, JSON, XML тощо).

Код на Django матиме такий вигляд. На традиційному веб-сайті, керованому даними, вебзастосунок чекає НТТР-запитів від браузера (або іншого клієнта). Після отримання запиту програма виконує те, що потрібно, виходячи з URL-адреси та інформації в POST даних або GET даних. Залежно від потреб інорормацію можна записати або прочитати з бази даних або виконати інші завдання, необхідні для виконання запиту. Додаток поверне відповідь до браузера, часто динамічно створюючи HTML-сторінку для відображення ним, вставляючи отримані дані в шаблоні HTML (рис. 1).

Веб-програми Django зазвичай групують код, який опрацьовує кожен із цих кроків, в окремі фрайли:

Здобувачам освіти у старшій школі під час вивчення веб-програмування слід повторити основні елементи мови HTML, опис їі засобами вебсторінок, створення інтерактивних веб-документів, а також ознайомитися 3 розробкою веб-сайтів із використанням мови програмування Python, тобто веб-орреймворку Django.

Вивчаючи веб-фрреймворк Django, слід звернути увагу на такі основні теми:

1. Налаштування середовища розробки Django.

2. Веб-сайт місцевої бібліотеки.

3. Створення шаблону веб-сайту.

4. Використання моделей.

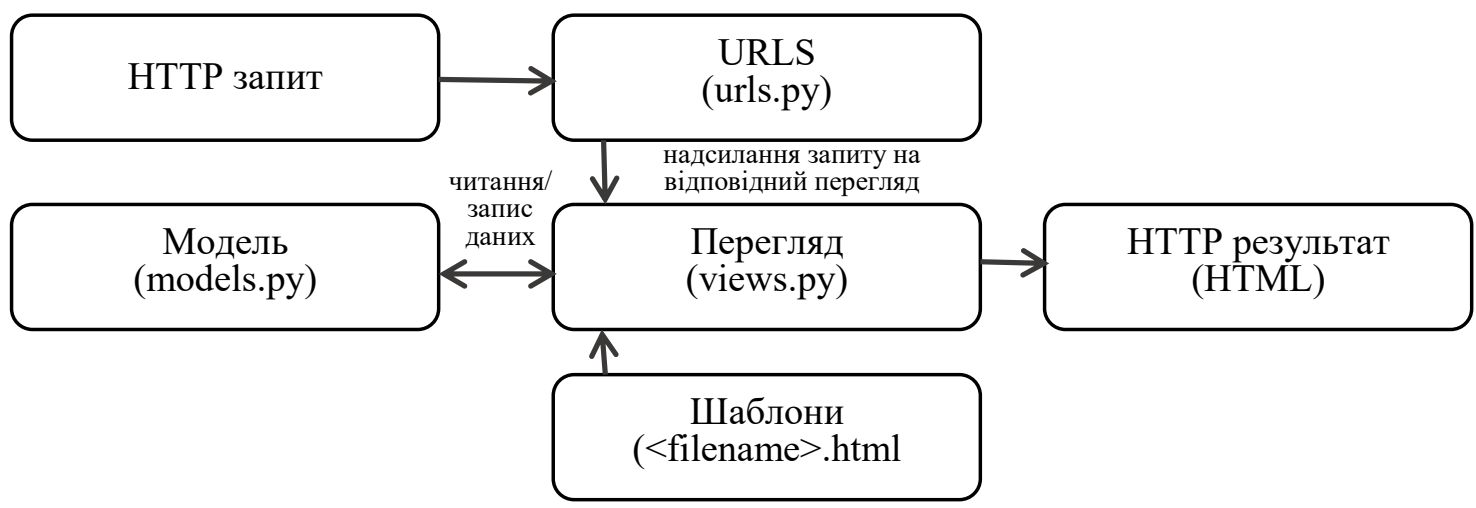

Рис. 1. Модель опрацювання HTML-сторінки браузером 
5. Сайт адміністратора Django.

6. Створення домашньої сторінки.

7. Автентифрікація та дозволи користувачів.

8. Робота з формами.

9. Тестування веб-застосунків Django.

10. Безпека веб-застосунків Django.

Висновки. У процесі дослідження нами були виконані поставлені завдання й отримані такі висновки: формування цифрових компетентностей учнів основної школи відбувається у процесі вивчення усіх предметно-змістових ліній навчального предмету «Інформатика»; вивчення вебпрограмування базується на елементах мови HTML, створенні інтерактивних веб-документів, а також ознайомленні з розробкою веб-сайтів мовою програмування Python, тобто веб-фреймворку Django. Очікується, що учні можуть обґрунтовувати доцільність використання мови програмування Python, веб-фрреймворку Django у своїй освітній діяльності, а також розробляти власні веб-сайти із застосуванням набутих знань.

\section{БІБЛІОГРАФІЧНИЙ СПИСОК:}

1. Биков В.Ю. Теоретико-методологічні засади створення і розвитку сучасних засобів та е-технологій навчання. Розвиток педагогічної і психологічної наук в Україні : збірник наукових праць до 10-річчя
АПН України. Академія педагогічних наук України. Ч. 2. Харків : «ОВС», 2002. С. 182-199.

2. ДорошенкоЮ.О., Завадський І.О., Прокопенко Н.С. Програма курсу за вибором «Основи Інтернет». Інфрорматика та інфрормаційні технології в навчальних закладах. 2006. № 4-5. С. 41-48.

3. Завадський І.О., Прокопенко Н.С. Програма курсу за вибором «Основи веб-дизайну». Інфрорматика та інформаційні технології в навчальних закладах. 2006. № 4-5. С. 48-55.

4. Кравцова А.Ю. Основные направления использования зарубежного опыта для развития методической системы подготовки учителей в области инфрормационных и коммуникационных технологий (теория и практика). Москва : Образование и Информатика, 2003. 232 с.

5. Кузьменко А.В., Рибак О.С. Основи верстки та веб-програмування (програма курсу за вибором). Комп'ютер у школі та сім'ї. 2017. № 5 (141). C. 41-47.

6. Національна стратегія розвитку освіти в Україні на період до 2021 р. / схвалена Указом Президента України від 25 червня 2013 р. № 344/2013. URL: http:// zakon2.rada.gov.ua/laws/show/344/2013 (дата звернення 24.11.2020).

7. Рамський Ю.С., Іваськів І.С., Ніколаєнко О.Ю. Вивчення Web-програмування в школі : навчальний посібник, Тернопіль : Навчальна книга Богдан, 2004. 200 c. 